Original Research

\title{
How Adding Biochar Improves Loessal Soil Fertility and Sunflower Yield on Consolidation Project Land on the Chinese Loess Plateau
}

\author{
Minmin Qiang1,3, Jian'en Gao ${ }^{1,2,3,4}$, Jianqiao Han ${ }^{1,2}$, Haochen Zhang ${ }^{1,3}$, \\ Tingwu Lin ${ }^{1,3}$, Shaobo Long1,3 \\ ${ }^{1}$ Institute of Soil and Water Conservation, Northwest A\&F University, Yangling, China \\ ${ }^{2}$ Institute of Soil and Water Conservation, Chinese Academy of Sciences and Ministry of Water Resources, \\ Yangling, China \\ ${ }^{3}$ Research Center on Soil and Water Conservation, Ministry of Water Resources, Yangling, China \\ ${ }^{4}$ Research Center of Soil and Water Conservation and Ecological Environment, \\ Chinese Academy of Sciences and Ministry of Education, Yangling, China
}

Received: 17 December 2019

Accepted: 14 February 2020

\begin{abstract}
Although a land consolidation project has increased arable land area in loess areas, the loessal soil has poor fertility and productivity. Soil degradation and the accompanying decline in crop yields are the main limiting factors for agricultural development on the Loess Plateau. Biochar has been used as an amendment to improve soil fertility and crop yields. A potted experiment was carried out to study the effects of biochar addition $\left(0,5,15\right.$ and $\left.25 \mathrm{t} \mathrm{ha}^{-1}\right)$ on soil physicochemical properties as well as sunflower yield. The results showed that higher rates of biochar addition $\left(15,25 \mathrm{t} \mathrm{ha}^{-1}\right)$ can significantly increase soil electrical conductivity, cation exchange capacity, nutrients and crop yields, while decreasing soil $\mathrm{pH}$. The maximum soil nutrients were observed at $25 \mathrm{tha}^{-1}$ biochar addition. However, the lowest soil $\mathrm{pH}$ value and highest sunflower seed yield were obtained at $15 \mathrm{tha}^{-1}$ biochar addition. The highest net income was $\$ 985 \mathrm{ha}^{-1}$ when the biochar addition rate was $15 \mathrm{tha}^{-1}$. These results suggest that biochar can significantly improve soil fertility and sunflower yield. Soil salinity and alkalinity properties, organic carbon, nitrate nitrogen and available phosphorus were crucial factors that determined soil fertility and sunflower yield in loessal soil.
\end{abstract}

Keywords: biochar, loessal soil, soil nutrient contents, soil fertility, sunflower yield

*e-mail: gaojianen@126.com 


\section{Introduction}

Loessal soil is widely distributed in areas with serious soil erosion in the Loess Plateau in China, which is the most important soil resource in this region [1]. However, loessal soil presents weak alkalinity, is highly erodible [2], has thin organic matter and nitrogen and available nutrients [3], and low abilities of water and fertility retention [4] - which all cause serious soil degradation and poor and unstable productivity [5].

To contain the serious soil erosion of the Loess Plateau, an important ecological engineering project called Grain for Green was implemented in 1999, and has since made marked benefits of soil and water conservation on the plateau [6,7]. However, the project also has caused a series of problems, such as a lack of arable land, leading to land resource strain and possibly food shortages [8-10]. As such, a "land consolidation" pilot project has been implemented to increase arable lands in Yan'an City since 2011. The project was listed as a major national project of land renovation by the Ministry of Land and Resources and Treasury in 2012 [11, 12]. Soil and water loss has been effectively controlled and land area has been greatly expanded since 2013, alleviating the conflicts between regional economic development, environmental protection and food security [13]. However, engineering measures such as leveling hills, filling valleys and constructing terraces greatly disturbed the plow-layer soil and transferred poor soil to the plough layer, and also adversely affected the soil environment and land productivity $[14,15]$. The created lands are detrimental to crop growth because of their low fertility and fragile ecological system [16, 17]. Therefore, exploring effective methods to rapidly improve soil fertility and environment of loessal soil in created land can be considered as important approaches for recovering degraded and low-productivity lands for agricultural development, and is pivotal for safeguarding the performance of land consolidation projects [18, 19].

Biochar is a high-carbon material produced by crop stalks, wood, livestock manure and other organic substances under low-oxygen or hypoxic conditions via high-temperature pyrolysis [20]. Numerous studies have shown the beneficial effects of biochar as a latemodel and pro-environmental amendment to improve soil fertility and eco-environmentalism [21-23]. Higher carbon content, large porous surface area, an abundance of negatively charged surfaces [24], a welldeveloped pore structure [25] and high stability have made biochar able to improve topsoil $(0-20 \mathrm{~cm})$ texture [26], increase water-holding capacity, enhance water infiltration [27, 28], and adsorb effective nutrients [29]. Some studies have indicated that peanut shell biochar addition improved topsoil properties and increased crop yield [30]. Furthermore, topsoil nutrients, soil biomass carbon, and soil enzyme activity have been shown to significantly increase in response to biochar and nitrogen fertilizer additions. Corn straw biochar can also reduce the loss of soil nutrients at $0-20 \mathrm{~cm}$ depth due to leaching and can increase the availability of the remaining soil nutrients [31]. With all these beneficial characteristics, biochar can increase crop yields and water and fertilizer use efficiency by providing a benign growth environment [32].

However, the effects of biochar on soil properties and sunflower yield in loessal soil generated from the land consolidation project in the Loess Plateau have not been thoroughly investigated, and the factors crucial for sunflower yield are not yet clear. Given the practical needs, it is important and urgent to improve soil fertility and land productivity for sustainable agricultural development on the plateau. Thus, the objective of this study was to evaluate the effect of biochar on soil fertility and sunflower biomass of created land on the Plateau. The results could provide a theoretical foundation and technological support for soil improvement and effective utilization of the newly created land.

\section{Material and Methods}

\section{Experimental Materials}

The program of land consolidation, filling gullies to create farmland so as to maximize the land use rate, involves the removal of soil from the surrounding hills and then using this to infill its channels while ensuring the safety of the maximum rainfall flood with a 20 -year return period in 6 hours in a small watershed no larger than $20 \mathrm{~km}^{2}$. The program of land consolidation includes a soil retaining dam, flood discharge channel, newly created land and gully and steep slope protection engineering. The soil samples experimented in this study were collected from slope with height of $50 \mathrm{~m}$ in Wanhuashan $\left(110^{\circ} 43^{\prime} \mathrm{E}, 36^{\circ} 50^{\prime} \mathrm{N}\right)$, Yan'an City, Shaanxi Province - examples of typical hilly and gully regions on the Loess Plateau. The tested soil was collected from the topsoil layer of newly created land in Yan'an, Shaanxi Province. The biochar used in this study was made from apple (Malus pumila Mill) tree branches at $600^{\circ} \mathrm{C}$ under anaerobic conditions and was provided by the Shaanxi Yi'xin Bioenergy and Technology Development Company, Ltd. The biochar had an initial $\mathrm{pH}$ of $8.8, \mathrm{EC}$ of $269.4 \mu \mathrm{S} \mathrm{cm} \mathrm{cm}^{-1}$, organic carbon of $414.7 \mathrm{~g} \mathrm{~kg}^{-1}$, total $\mathrm{N}$ of $2.1 \mathrm{~g} \mathrm{~kg}^{-1}$, total $\mathrm{P}$ of $11.6 \mathrm{~g} \mathrm{~kg}^{-1}$, total $\mathrm{K}$ of $9.3 \mathrm{~g} \mathrm{~kg}^{-1}$, and cation exchange capacity of $13.4 \mathrm{cmol} \mathrm{kg}^{-1}$. The biochar was ground and then passed through a $2 \mathrm{~mm}$ screen for the experiment.

\section{Pot Experiment}

Plastic containers were used for the pot experiment. The containers had a uniform size: a $33 \mathrm{~cm}$ diameter, a $24 \mathrm{~cm}$ bottom diameter and $30 \mathrm{~cm}$ height. Eighteen kilograms of soil (layers of a height of approximately $25 \mathrm{~cm}$ ) were added to each container. The soil had 


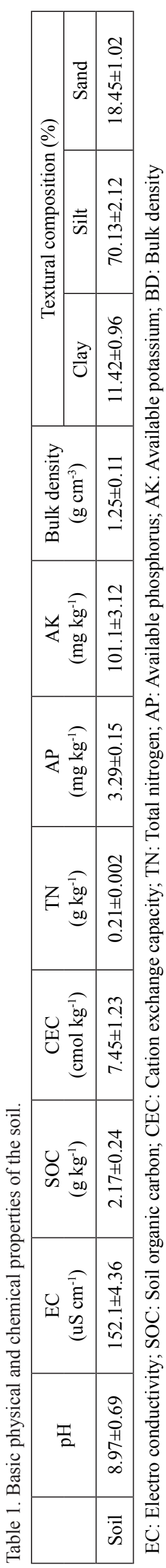

an initial mass moisture content of $11.5 \%$, and the soil bulk density was $1.25 \mathrm{~g} / \mathrm{cm}^{3}$. Four holes with an $8 \sim 10 \mathrm{~mm}$ aperture were drilled at the bottom of the plastic containers for drainage and ventilation. The plastic containers were placed in the open under natural sunshine and were rained upon. The sunflowers selected for the experiment were planted three days later.

Four biochar rates $\left(5,15,25\right.$, and $0 \mathrm{t} \mathrm{ha}^{-1}$, labeled as T1, T2, T3 and T4 treatments) with basal fertilizer of $35 \mathrm{~kg} \mathrm{~N} \mathrm{ha}^{-1}$ and $17.5 \mathrm{~kg} \mathrm{P}_{2} \mathrm{O}_{5} \mathrm{ha}^{-1}$ and only sunflower (labeled as T5) and only loessal soil (labeled as CK) were designed. All the pot plots were designed with three replications. The treatments of T1, T2, T3 and T4 received a basal fertilizer of $35 \mathrm{~kg} \mathrm{~N} \mathrm{ha}^{-1}$ and $17.5 \mathrm{~kg} \quad \mathrm{P}_{2} \mathrm{O}_{5} \quad \mathrm{ha}^{-1}$ through urea and potassium dihydrogen phosphate, respectively. Biochar and N, P fertilizer were uniformly mixed into the soil to a depth of approximately $20 \mathrm{~cm}$ on August 11, 2017. The control plots were mixed in the same manner as the other plots to maintain consistency, though without the addition of biochar or N, P fertilizer. No further biochar and N, P fertilizer were added for the duration of the study. With respect to the pot experiment, sunflowers were planted from August 14, 2017, to October 30, 2017. Each pot contained 3 crops. During the crop growth stage, the crops were artificially irrigated in a timely manner as appropriate in accordance with the climate and growth conditions in order to ensure normal sunflower growth and development.

\section{Sample Collection and Laboratory Analysis}

In the stage of crop growth, we measured sunflower (helianthus annuus Linn) height (from ground to the top), leaf length and leaf width (the three leaves from above) over 10 days.

Soil sampling: we collected soil samples at 30,60 and 90 days after planting, the soils were collected. Three replicated soil samples were collected from each plot at a depth of $0-20 \mathrm{~cm}$ using a hand auger with a $2.1 \mathrm{~cm}$ diameter. All soil samples were stored at $4^{\circ} \mathrm{C}$ in a laboratory. Soil samples were air-dried, ground and passed through $0.15 \mathrm{~mm}, 1 \mathrm{~mm}$ and $2 \mathrm{~mm}$ diameter meshes for soil physical and chemical analyses.

SOC was measured by the potassium dichromate oxidation method after digestion with concentrated sulfuric acid [33]. The TN content was determined by semimicro Kjeldahl method, and available phosphorus (AP) was measured by treatment with $0.5 \mathrm{~mol} 1-1$ $\mathrm{NaHCO}_{3}$ followed by the molybdenum blue colorimetry method using a UV-2300 spectrophotometer (Tianmei Technology Company, China). The cation exchange capacity (CEC) was measured by sodium acetate-flame photometry [34]. Ammonia nitrogen (AN) and nitrate nitrogen (NN) were determined by a continuous flow analyzer (AutAnalyel 3, AAA, America). Available K (AK) was determined using a flame photometer (M410, Sherwood, England). 
Soil $\mathrm{pH}$ and electrical conductivity (EC) were measured using a conductivity meter (DDS-307A, INESA, China) and a $\mathrm{pH}$ meter (pHS-3E, INESA, China), respectively. The soil bulk density (BD) was determined by using the cutting ring method [35]. Soil particle size was measured using a laser particle analyzer (APA2000, Marvin company, England) by calculating the proportions of sand $(0.05-2 \mathrm{~mm})$, silt $(0.002-0.05 \mathrm{~mm})$ and clay $(<0.002 \mathrm{~mm})$. The soil type in the study area is a silty loam based on the international classification criterion of the U.S. Department of Agriculture. The basic properties of the soil are given in Table 1.

\section{Harvest}

After harvest, sunflower plants were cut, removed and placed into clean bags. The crop material was then dried in an oven at $90^{\circ} \mathrm{C}$ for 30 minutes. The aboveground biomass of the sunflowers was subsequently measured once the material had dried to a constant weight at $60^{\circ} \mathrm{C}$. We measured the dry matter quantity of leaf, stem and flower dish and dry weight of the sunflower seeds in each plot and then converted into a measure of unit area yield $\left(\mathrm{t} \mathrm{ha}^{-1}\right)$.

The leaf area was determined in accordance with the formula of length $\times$ width $\times$ coefficient.

\section{The Economic Benefit Model}

In this study, we only consider the costs of biochar and chemical fertilizer and the crop's economic income to calculate the net income and to study the more optimal biochar rate. The net income is calculated below:

$$
N I=O P-I P
$$

...where NI is the net income $\left(\$ \mathrm{ha}^{-1}\right)$, OP is the economic output in each treatment $\left(\$ \mathrm{ha}^{-1}\right)$, IP is the biochar and chemical fertilizer total input of urea and potassium dihydrogen phosphate in each treatment $\left(\$ h^{-1}\right)$.

$$
\begin{gathered}
O P=Y \times U P \\
I P=T B+T N+T P
\end{gathered}
$$

...where $\mathrm{Y}$ is the sunflower yield $\left(\mathrm{t} \mathrm{ha}^{-1}\right)$; UP is the unit price of sunflower seeds $\left(\$ \mathrm{t}^{-1}\right)$; and $\mathrm{TB}, \mathrm{TN}, \mathrm{TP}$ are the costs of biochar, urea and potassium dihydrogen phosphate in each treatment.

\section{Statistical Analysis}

The analysis of the data was performed using the SPSS 20.0 statistical package. One-way ANOVA was used to analyze the effects of biochar addition on the loessal soil properties and sunflower yield, and the least significant difference (LSD) at $\mathrm{p}<0.05$ were used to compare the differences between the treatment means. An Origin 9.0 was used to draw the figures.

\section{Results and Discussion}

\section{Soil $\mathrm{pH}, \mathrm{EC}$ and CEC}

We measured the dynamic changes of soil $\mathrm{pH}, \mathrm{EC}$ and CEC during the crop-growing season. The biochar combined with chemical fertilizer can decrease soil $\mathrm{pH}$ (Fig. 1a). The effectiveness improved with the amount of biochar, and the difference among biochar treatments increased at high adding rates. The $\mathrm{pH}$ value of the soil decreased in response to the biochar addition. However, the $\mathrm{pH}$ value first sharply decreased and then increased at one level of biochar rate, and the soil $\mathrm{pH}$ with $15 \mathrm{t} \mathrm{ha}^{-1}$ biochar reached the lowest value after 30 days of biochar addition. Hereafter, the soil $\mathrm{pH}$ values of all biochar treatments increased during the crop growth period. At the end of the experiment, T2 still had a significant $(p<0.05)$ decrease in soil $\mathrm{pH}$ (by 0.26 unit over $\mathrm{CK}$ ). Compared with the $\mathrm{CK}$ treatment, the $\mathrm{pH}$ values in $\mathrm{T} 1, \mathrm{~T} 3$, and $\mathrm{T} 4$ treatments were reduced by $0.31-0.13$ units, although less dramatically.
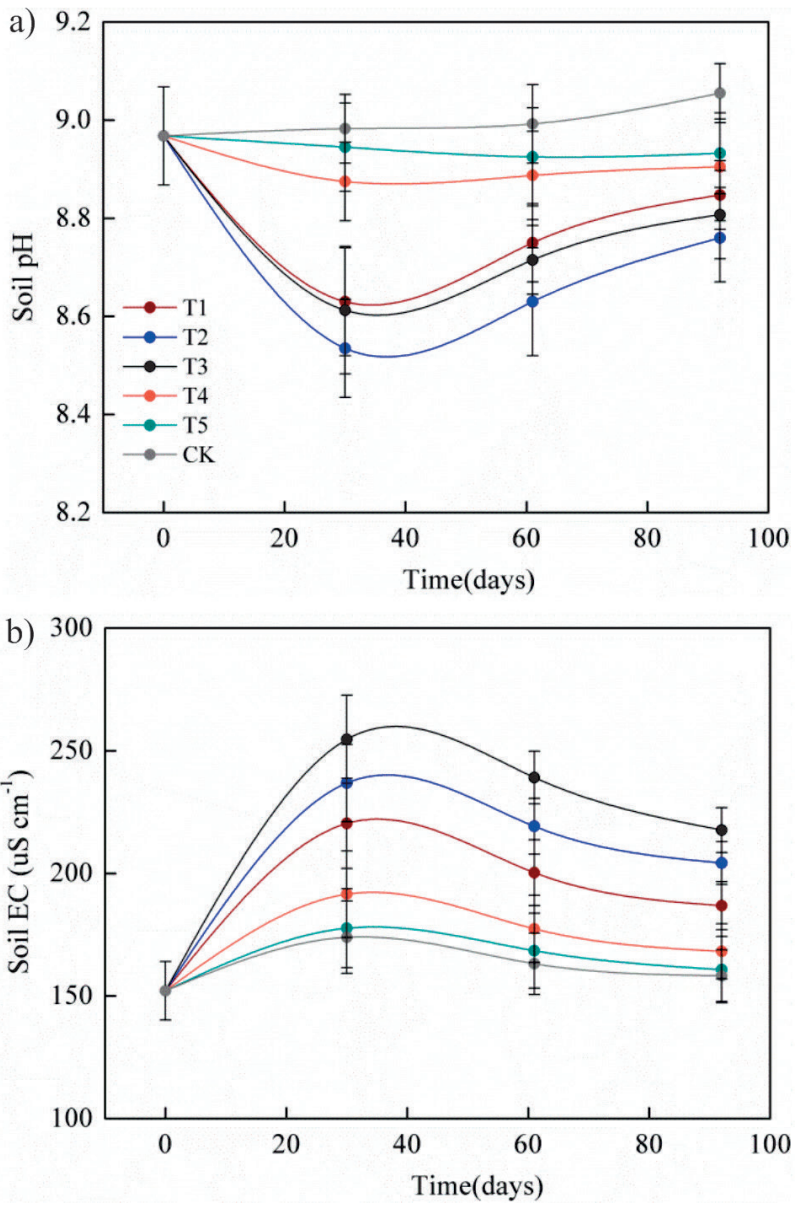

Fig. 1. Effect of biochar on $\mathrm{pH}$ and $\mathrm{EC}$ of loessal soil $(\mathrm{n}=3$; means and standard deviation). 


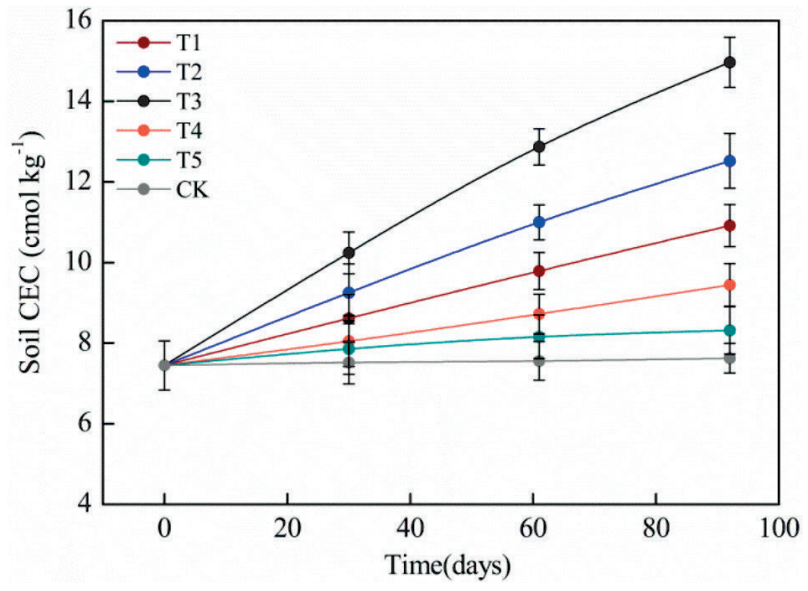

Fig. 2. Effect of biochar on the CEC of loessal soil in created land $(\mathrm{n}=3$; means and standard deviation).
Fig. 1b) shows the variation in soil EC during the growing season. Soil EC increased rapidly and declined from their peaks of 30 days. Soil EC increased with the increasing biochar addition rate. Hereafter, soil EC of all biochar treatments decreased during the crop growth period. Compared with CK treatment, soil EC in T1, $\mathrm{T} 2$, and $\mathrm{T} 3$ treatments increased by $15.2 \sim 34.2 \%$. The biochar treatments of T2, T3 saw significant increases in soil EC $(p<0.05)$.

The results of this study provide evidence to the effectiveness of biochar in reducing soil salinity and alkalinity and improving soil fertility. The given biochar $\mathrm{pH}$ value is lower than that of test soil. Therefore, the fact that soil $\mathrm{pH}$ values decreased in early days after being mixed with biochar is no surprise. However, the basic cations of biochar and negative charge on the biochar surface can exchange ions with $\mathrm{H}^{+}$in
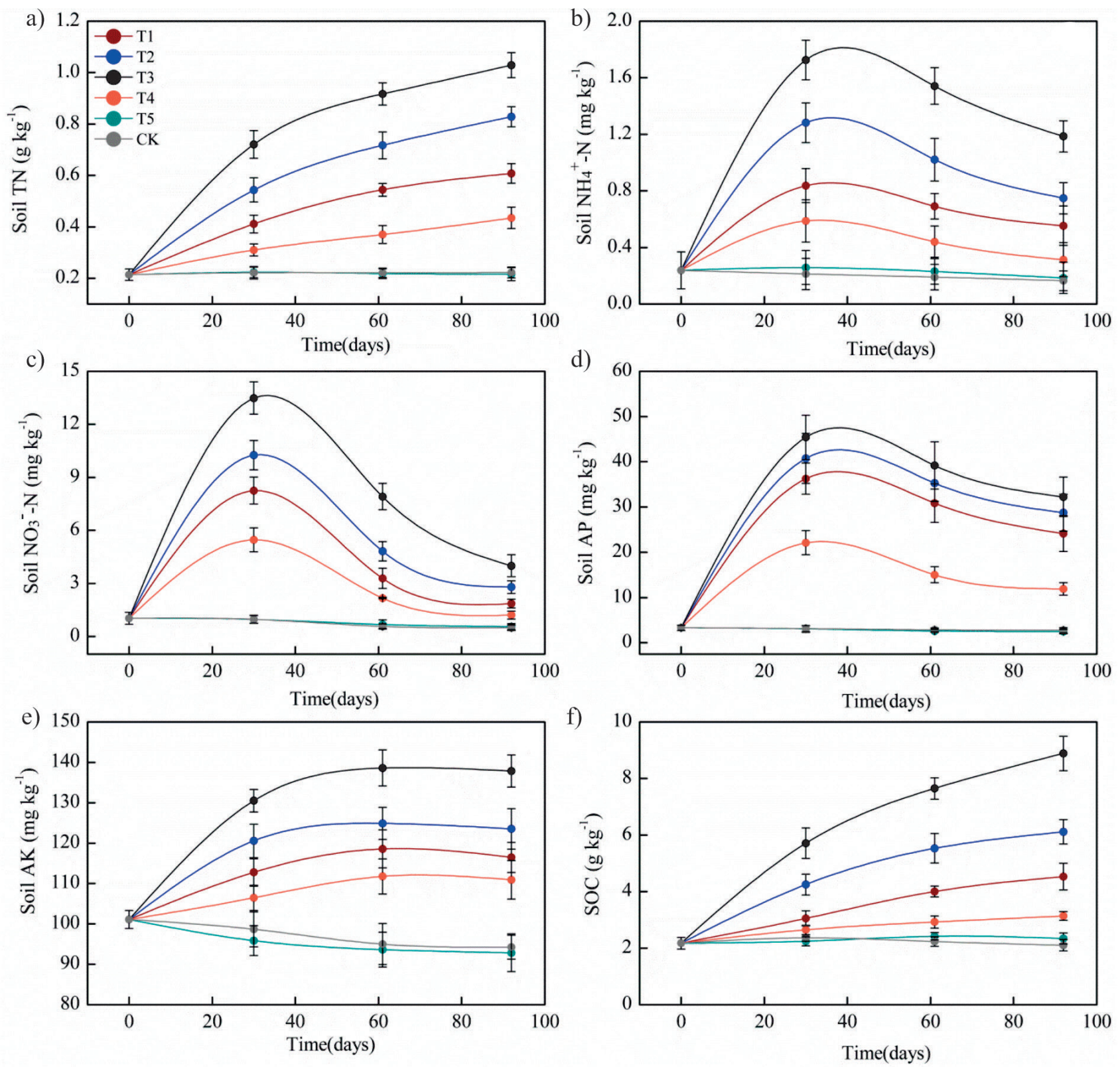

Fig. 3. Effects of biochar on nutrients of loessal soil $(\mathrm{n}=3$; means and standard deviation). 
soil solutions [36], which will enhance base saturate rate and increase soil $\mathrm{pH}$ values [37]. It was also demonstrated that soil EC increased with the increasing biochar addition rate [38]. The salinity in deeper soil layers ascended and accumulated near the surface due to the processes of irrigation, high evaporation and transpiration at the early stages [39]. Thereafter, soil EC was reduced with the increase of biochar addition soil CEC, which was determined by the specific surface area and surface negative charge density of soil colloids, which is an important indicator of soil fertility [40].

Soil CEC indicate the ability of the soil to absorb and supply exchangeable nutrients and can also be used to characterize soil fertility. The effectiveness on CEC improved with the amount of biochar, and the difference among biochar treatments increased at high adding rates (Fig. 2). Soil CEC continues to increase after biochar was applied and linearly increased during the crop growth period. Biochar addition with $25 \mathrm{t} \mathrm{ha}^{-1}$ showed the greatest increase in soil CEC. Compared with CK treatment, soil CEC in the T1, T2, T3, and T4 treatments increased by $23.8 \sim 96.2 \%$. The significant increase in soil CEC was found under biochar addition treatments of T1, T2, T3 conditions $(p<0.05)$.

Due to its huge specific surface area and anionic charge [41], biochar increased the ability of the soil to absorb cations and enabled a greater CEC in the topsoil [42], which also resulted in the synthesis of an abundance of compounds with aromatic structures and hydroxyl carboxyl [23]. Therefore, the formation of CEC was accelerated when the soil organic carbon of newly created land increases in response to N-biochar addition. The interaction among soil elements would further promote soil quality.

\section{Soil Organic Carbon and Available Nutrients}

The dynamic changes in soil total nitrogen, $\mathrm{NH}_{4}{ }^{+}-\mathrm{N}$ and $\mathrm{NO}_{3}^{-}-\mathrm{N}$, available $\mathrm{P}$ and available $\mathrm{K}$ during crop growth season are shown in Fig. 3. Overall, biochar significantly increased soil total nitrogen, available $\mathrm{P}$ and available $\mathrm{K}$ contents $(p<0.05)$. Biochar effectiveness improved with the increasing addition amount, and the difference among biochar treatments increased at high addition rates. Compared with $\mathrm{CK}$ treatment, soil total nitrogen, available $\mathrm{P}$ and available $\mathrm{K}$ contents saw their greatest increase in T3 treatment and increased by $362 \%, 896 \%$ and $46.3 \%$, respectively $(p<0.05)$. Soil $\mathrm{NH}_{4}^{+}-\mathrm{N}$ and $\mathrm{NO}_{3}^{-}-\mathrm{N}$ increased rapidly until they peaked after 60 and 30 days, respectively. The peak values of $\mathrm{NH}_{4}^{+}-\mathrm{N}\left(1.7 \mathrm{mg} \mathrm{kg}^{-1}\right)$ and $\mathrm{NO}_{3}^{-}-\mathrm{N}$ (13.5 $\mathrm{mg} \mathrm{kg}^{-1}$ ) were measured in $\mathrm{T} 3$ treatment with $25 \mathrm{t} \mathrm{ha}^{-1}$ biochar addition. Thereafter, the $\mathrm{NH}_{4}^{+}-\mathrm{N}$ and $\mathrm{NO}_{3}^{-}-\mathrm{N}$ contents sharply decreased. At the end of the experiment, soil $\mathrm{NH}_{4}^{+}-\mathrm{N}$ and $\mathrm{NO}_{3}^{-}-\mathrm{N}$ declined by $31.3 \%$ and $70.4 \%$ in $\mathrm{T} 3$ treatment after the peak values.
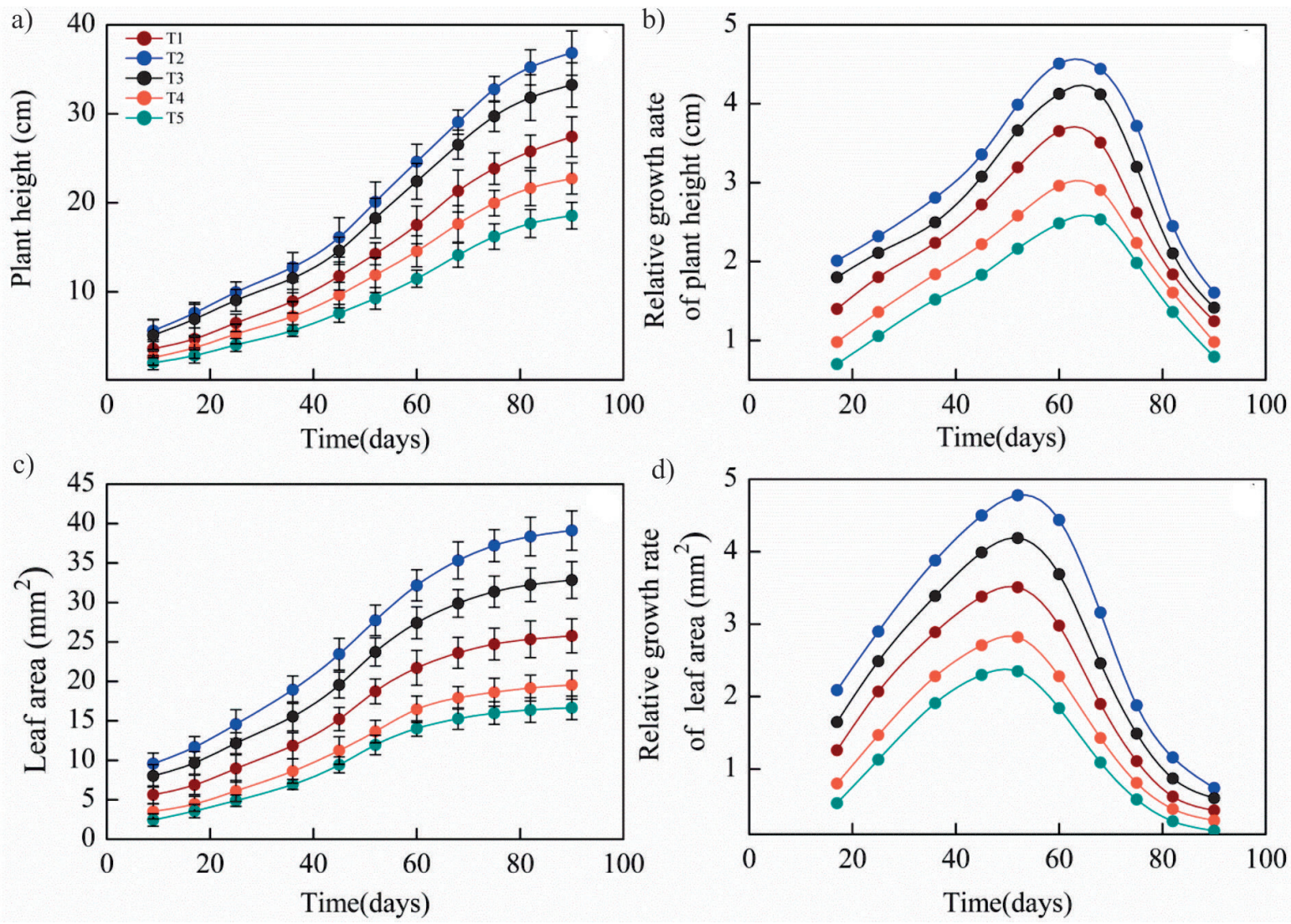

Fig. 4. Effects of biochar application on the growth of sunflower $(n=3$; means and standard deviation). 
Biochar addition revealed a positive effect on SOC content (Fig. 3f). SOC contents were significantly higher at a high biochar addition rate $\left(25 \mathrm{t} \mathrm{ha}^{-1}\right)$ than that at low biochar addition rate $\left(5 \mathrm{t} \mathrm{ha}^{-1}\right)$ and CK. However, the effect of biochar on SOC appeared to stabilize over time. The greatest SOC content $\left(8.9 \mathrm{~g} \mathrm{~kg}^{-1}\right)$ was found in the T3 treatment with $25 \mathrm{t} \mathrm{ha}^{-1}$ biochar addition. Compared with $\mathrm{CK}$ treatment, SOC contents in the $\mathrm{T} 1, \mathrm{~T} 2, \mathrm{~T} 3$, and $\mathrm{T} 4$ treatments increased by $32.2 \sim 49.2 \%$. The significant increase in SOC was found under biochar addition treatments of T1, T2, and T3 conditions $(p<0.05)$.

SOC, $\mathrm{N}$ and $\mathrm{P}$ are the main limit factors of crop growth [43]. The poor development structure and serious soil and water erosion of loessal soil have resulted in lower $\mathrm{N}$, available $\mathrm{P}$ and SOC and a decrease of land productivity [44]. As we measured biochar to be a potential N, P and SOC source, Li et al. [45] also found that branch biochar has high contents of $\mathrm{N}, \mathrm{P}$ and SOC. In this paper, soil total $\mathrm{N}$, available $\mathrm{P}$ and SOC were significantly increased after biochar and chemical fertilizer was applied. Combined with the aim of land consolidation and biochar addition, we need to facilitate the assimilation and transformation of $\mathrm{N}$ in loessal soil, instead of blindly inputting the nitrogen source [46], and this effect was observed in our experiment. The results showed that biochar can increase the concentrations of $\mathrm{NH}_{4}^{+}-\mathrm{N}$ and $\mathrm{NO}_{3}^{-}-\mathrm{N}$ and effectively supplement the soil mineral nitrogen. The nitrification of $\mathrm{NH}_{4}^{+}-\mathrm{N}$ later could decrease soil alkalinity over time [47, 48]. This result will increase soil available $P$ content [49]. In addition, biochar can adsorb various ions to promote fertilizer retention capacity because of the high specific surface area [50]. Biochar also can bind $\mathrm{Al}$ and $\mathrm{Fe}$ ions to facilitate the effectiveness of $\mathrm{P}$ and increase soilavailable P [51]. Glaser et al. [22] also reported that the stabilized carbon of biochar accumulated in soil, which accelerated the formation of soil aggregates, improved the soil environment and increased soil organic carbon through the absorption of soil organic molecules. Moreover, biochar can facilitate the polymerization of small organic molecules into soil organic carbon compounds [52]. Biochar also increased soil adsorption of $\mathrm{K}$ ion and reduced leaching losses of available $\mathrm{K}$ in the plateau [53].

\section{Crop Growth and Yield}

The dynamic changes in crop growth, including plant height, stem diameter and leaf area, in response to the amounts of biochar addition, are shown in Fig. 4. The crop growth curve showed a double S form. The plant height, stem diameter and leaf area of sunflower increased over time. The effects of biochar on crop growth increased with the addition amount, and the difference among biochar treatments increased at high adding rates. Moreover, the effects of biochar and chemical fertility addition treatments were greater than those of chemical fertilizer treatments and CK. The relative growth rate of plant height of about $4.4 \mathrm{~cm}$ peaked in $\mathrm{T} 2$ treatment at nearly 70 days. The greatest relative growth rate of leaf area $\left(4.8 \mathrm{~mm}^{2}\right)$ was measured in $\mathrm{T} 2$ treatment with $15 \mathrm{t} \mathrm{ha}^{-1}$ biochar addition at 50 days. However, growth rates of crop height and stem diameter and leaf area have the greatest values when the amount of biochar addition was $15 \mathrm{t} \mathrm{ha}^{-1}$ (T2). Compared with the CK treatment, plant height and leaf area in T2 treatments increased by $98.4 \%$ and $135 \%$, respectively. The significant increase in plant height and leaf area was found under biochar treatments of T1, T2, and T3 conditions $(p<0.05)$.

The effects of biochar addition on plant fresh weight and dry weight of the overground and crop yield are shown in Table 2. Sunflower over weights and seed yields increased with the biochar addition. Overall, biochar had a positive effect on sunflower growth and seed yields. Plant height, stem diameter, hundred seeds weight, fresh weight and dry weight of the aboveground elements were significantly higher $(p<0.05)$ in biochar addition treatments than in the CK. However, a higher biochar addition rate is not necessarily better for sunflower seed yields. The highest sunflower seed yield of $1.31 \mathrm{t} \mathrm{ha}^{-1}$ was recorded in the $\mathrm{T} 2$ treatment with $15 \mathrm{t} \mathrm{ha}^{-1}$ biochar addition. Also, plant stem diameter, hundred seeds weight, fresh weight and dry weight of the aboveground elements in T2 treatment reached maximum. The net income of sunflower seed yields showed that biochar can increase sunflower economic income (Table 2). Due to the effect of biochar on soil fertility, crop yields and the expenditure, the superfluous addition of biochar would be detrimental to soil and reduce net income. The highest net income

Table 2. Effect of biochar addition on crop yield and yield components.

\begin{tabular}{|c|c|c|c|c|c|c|}
\hline Treatment & $\begin{array}{c}\text { Stem diameter } \\
(\mathrm{cm})\end{array}$ & $\begin{array}{c}\text { Hundred grains } \\
\text { weight }(\mathrm{g})\end{array}$ & $\begin{array}{c}\text { Fresh Weight } \\
(\mathrm{g})\end{array}$ & $\begin{array}{c}\text { Dry weight } \\
(\mathrm{g})\end{array}$ & $\begin{array}{c}\text { Yield } \\
\left(\mathrm{t} \mathrm{ha}^{-1}\right)\end{array}$ & $\begin{array}{c}\text { Net income } \\
\left(\$ \mathrm{ha}^{-1}\right)\end{array}$ \\
\hline T1 & $3.1 \pm 0.12 \mathrm{c}$ & $6.5 \pm 0.41 \mathrm{c}$ & $52.45 \pm 3.54 \mathrm{c}$ & $41.97 \pm 4.49 \mathrm{c}$ & $0.95 \pm 0.11 \mathrm{~b}$ & 784 \\
\hline T2 & $4.3 \pm 0.15 \mathrm{a}$ & $8.4 \pm 0.47 \mathrm{a}$ & $72.47 \pm 6.47 \mathrm{a}$ & $56.23 \pm 5.78 \mathrm{a}$ & $1.31 \pm 0.17 \mathrm{a}$ & 985 \\
\hline T3 & $3.8 \pm 0.11 \mathrm{~b}$ & $7.7 \pm 0.34 \mathrm{~b}$ & $68.45 \pm 4.32 \mathrm{ab}$ & $54.61 \pm 6.03 \mathrm{ab}$ & $1.12 \pm 0.13 \mathrm{ab}$ & 929 \\
\hline T4 & $2.7 \pm 0.07 \mathrm{~cd}$ & $6.2 \pm 0.39 \mathrm{~cd}$ & $45.1 \pm 5.14 \mathrm{~d}$ & $35.2 \pm 3.97 \mathrm{~d}$ & $0.63 \pm 0.15 \mathrm{c}$ & 525 \\
\hline T5 & $2.4 \pm 0.09 \mathrm{~d}$ & $5.8 \pm 0.54 \mathrm{~d}$ & $40.24 \pm 5.73 \mathrm{e}$ & $31.86 \pm 5.12 \mathrm{e}$ & $0.41 \pm 0.12 \mathrm{~d}$ & 405 \\
\hline
\end{tabular}

Lowercase letters indicate significant differences among treatments at 0.05 levels. 
Table 3. Correlation analysis of soil properties and crop yield and yield components.

\begin{tabular}{|c|c|c|c|c|c|c|}
\hline $\begin{array}{c}\text { Correlation } \\
\text { coefficient }\end{array}$ & Yield & Plant Height & Stem Diameter & $\begin{array}{c}\text { Hundred } \\
\text { Seeds Weight }\end{array}$ & Fresh Weight & Dry weight \\
\hline $\mathrm{pH}$ & $-0.984^{* *}$ & $-0.996^{* *}$ & $-0.996^{* *}$ & $-0.986^{* *}$ & $-0.996^{* *}$ & $-0.992^{* *}$ \\
\hline $\mathrm{EC}$ & $-0.948^{*}$ & $-0.945^{*}$ & $-0.898^{*}$ & -0.872 & $-0.892^{*}$ & $-0.888^{*}$ \\
\hline $\mathrm{CEC}$ & 0.865 & 0.870 & 0.852 & 0.839 & $0.909^{*}$ & $0.928^{*}$ \\
\hline $\mathrm{TN}$ & 0.779 & 0.805 & 0.812 & 0.819 & $0.880^{*}$ & $0.898^{*}$ \\
\hline $\mathrm{SOC}$ & $0.826^{*}$ & 0.846 & 0.848 & $0.849^{*}$ & $0.909^{*}$ & $0.926^{*}$ \\
\hline $\mathrm{NH}_{4}^{+}-\mathrm{N}$ & 0.823 & 0.840 & 0.830 & 0.828 & $0.894^{*}$ & $0.912^{*}$ \\
\hline $\mathrm{NO}_{3}^{-}-\mathrm{N}$ & $0.882^{*}$ & $0.879 *$ & 0.838 & $0.817^{*}$ & $0.884^{*}$ & $0.900^{*}$ \\
\hline $\mathrm{AP}$ & $0.838^{*}$ & 0.869 & 0.834 & 0.836 & $0.860^{*}$ & $0.858^{*}$ \\
\hline $\mathrm{AK}$ & 0.749 & 0.800 & 0.787 & 0.809 & 0.836 & 0.838 \\
\hline
\end{tabular}

One asterisk and two asterisks indicate significant differences at $p<0.05$ and $p<0.01$, respectively.

would be $\$ 985 \mathrm{ha}^{-1}$ when the addition rate of biochar is $15 \mathrm{t} \mathrm{ha}^{-1}$

Crop growth and yield reflected the comprehensive presentation of intrinsic soil attributes. To some extent, soil fertility is directly related to crop yield [54]. The result showed greatest crop growth and highest seed yield in the medium addition of $15 \mathrm{t} \mathrm{ha}^{-1}$ biochar. In this study, soil $\mathrm{pH}$ decreased first and then increased after biochar addition. The minimal $\mathrm{pH}$ values result from T2 treatment, and not from T3. Crop growth was sensitive to soil salinity and alkalinity in the seedling, blossoming and bearing fruits stages. High soil salinity and alkalinity greatly affected the growth and development of the plant and productivity crops. In addition, soil $\mathrm{pH}$ and salinization indirectly influenced soil microbial activities and enzymatic activities. A previous study indicated that soil $\mathrm{pH}$ was the primary control over microbial activity because $\mathrm{pH}$ controls microbial enzyme production, carbon and nutrient availabilities [55]. Inorganic nitrogen produced by soil nitrogen mineralization was the main source of nitrogen for plants. Other possible mechanisms could be the effect of soil acidity and alkalinity on the activities of microbes in nitrifying and ammonifying. Ding et al. [56] found that the alkalescent soil environment was beneficial to nitrogen ammonification and nitration. In line with Steiner et al. [57], crop yield declined because of the negative effect of biochar on soil alkalinity due to excessive biochar addition. However, Jin et al. [58] came to opposite conclusions that soil fertility and crop yield continuously increase in red soil with the increased biochar addition rates. These results were probably due to the different acidity and alkalinity of the soil. Furthermore, N-biochar addition enhanced the conservation of water and fertility while decreasing the loss of nutrients and improving both nutrient use efficiency and sustainability of land use.

The results showed that the maximum seed yield of sunflower was obtained in the medium addition rate of $15 \mathrm{t} \mathrm{ha}^{-1}$ biochar. This indicated that a high biochar addition rate is not always economically feasible [59]. Considering cost-effectiveness, the highest net income is $\$ 985 \mathrm{ha}^{-1}$ when the addition of biochar and nitrogen and $\mathrm{P}_{2} \mathrm{O}_{5}$ fertilizer were $15 \mathrm{t} \mathrm{ha}^{-1}, 35 \mathrm{~kg} \mathrm{ha}^{-1}$ and $17.5 \mathrm{~kg} \mathrm{ha}^{-1}$, respectively. The benefits of improving their soil and rising economic gains should be enough to persuade farmers to make and bury biochar. Biochar has long-term effects and also can reduce chemical fertilizer application to protect environment [60].

\section{Key Factors of Soil Fertility and Sunflower Yield}

In this paper, we also have an objective to explore the effects of soil $\mathrm{pH}, \mathrm{EC}, \mathrm{CEC}$ and soil nutrients on crop yields (Table 3). A significance of $p<0.01$ revealed a very significant negative relationship between soil $\mathrm{pH}$ and crop yield. Soil EC had a significantly negative relationship with crop yield at a significance of $p<0.05$. There are significant positive relationships among SOC, $\mathrm{NO}_{3}^{-}-\mathrm{N}$ and available $\mathrm{P}$ and crop yield. Soil $\mathrm{pH}$ value also had a significant negative effect on sunflower yield components. Hundred seeds weight was mainly influenced by soil $\mathrm{pH}$ and SOC.

There was a positive effect of biochar addition on crop growth and yield, which was consistent with Liang et al. [61] and Luo et al. [52], who found that branch biochar improved crop yield by increasing soil CEC, N, $\mathrm{P}, \mathrm{K}$ and SOC in alkaline soil. Moreover, the activity of soil microorganisms and the growth and development of crop roots are promoted by vitamins and hormones within the increased soil organic carbon content, which provides necessary nutrients and microelements for crop growth [62]. However, crop yield declined because of the negative effect of biochar on soil salinity and alkalinity [57]. We suggest that famers add biochar with $15 \mathrm{t} \mathrm{ha}^{-1}$ to reach maximize profits. 


\section{Conclusions}

The results presented here suggest that biochar can significantly enhance soil CEC and nutrient contents while lowering $\mathrm{pH}$. However, the effect of biochar on loessal soil $\mathrm{pH}$ weakened at a high biochar addition rate $\left(>25 \mathrm{t} \mathrm{ha}^{-1}\right)$. Our result also found that biochar can increase sunflower yield. The correlation analysis showed that soil $\mathrm{pH}, \mathrm{EC}, \mathrm{SOC}, \mathrm{NO}_{3}^{-}-\mathrm{N}$ and $\mathrm{AP}$ have more significant effects on soil fertility and sunflower yield. The hundred seeds weight is the main controlling yield component of sunflower yield. We believe that soil salinity and alkalinity properties, $\mathrm{SOC}, \mathrm{NO}_{3}^{-}-\mathrm{N}$ and AP are key factors of soil fertility and sunflower yield in loessal soil on the Loess Plateau. Biochar can enhance hundred seeds weight by enhancing soil $\mathrm{pH}, \mathrm{EC}, \mathrm{SOC}, \mathrm{NO}_{3}^{-}-\mathrm{N}$ and $\mathrm{AP}$, and then increasing sunflower yield.

\section{Acknowledgements}

This paper was supported by the National Key R\&D Program of China (2017YFC0504703), the National Natural Science Foundation of China (41877078, 41371276), the Basic Research Program in Natural Sciences of Shaanxi Province, China (2016ZDJC-20), Shaanxi Province Science and Technology Innovation Project (2013KTDZ03-03-01), and the knowledge innovation program of the Chinese Academy of Sciences (A315021615).

\section{Conflict of Interest}

The authors declare no conflict of interest.

\section{References}

1. CHEN Y.F., LIU Y.S., WANG J., YAN J.P., GUO X.D. Land Use Changes of an Aeolian-Loessial Soil Area in Northwest China: Implications for Ecological Restoration. Pedosphere, 19 (03), 356, 2009.

2. CHENG Q.J., MA W.J., CAI Q.G. Responses of rain splash erosion and soil crust development to particle size. China Academic Journal Electronic Publishing House, 44 (3), 392, 2007.

3. HAN L., LI R., ZHU H.L. Research on the current farmland soil nutrient in Ansai. Journal of Northwest Agriculture and Forest University, 39 (5), 91, 2011.

4. WANG H.F., XIAO B., WANG M.Y., SHAO M.A. Modeling the Soil Water Retention Curves of Soil-Gravel Mixtures with Regression Method on the Loess Plateau of China. Plos One, 8 (3), e59475, 2013.

5. BAI Y.H., HE J., LI H.W., WANG Q.J. Soil Structure and Crop Performance After 10 Years of Controlled Traffic and Traditional Tillage Cropping in the Dryland Loess Plateau in China. Soil Science, 174 (2), 113, 2009.

6. XUE Y.Y., WAN X.F. Evaluation on soil conservation effect of returning cropland to forest and grassland in forest-steppe zone of loess plateau. Agricultural Research in the Arid Areas, 35 (5), 128, 2017.

7. CHANG R.Y., FU B.J., LIU G.H., LIU S.G. Soil carbon sequestration potential for "grain for green" project in loess plateau, china. Environmental Management, 48 (6), 1158, 2011.

8. CHEN D.J., HU M.P., GUO Y., DAHLGREN R.A. Influence of legacy phosphorus, land use and climate change on anthropogenic phosphorus inputs and riverine export dynamics. Biogeochemistry, 123 (1-2), 99, 2015.

9. FENG Z.M., YANG Y.Z., ZHANG Y.Q., ZHANG P.T., LI Y.Q. Grain-for-green policy and its impacts on grain supply in West China. Land Use Policy, 22 (4), 301, 2005.

10. XU Z.G., XU J., DENG X.Z., HUANG J.K., UCHIDA E., ROZELLE E. Grain for Green versus Grain: Conflict between Food Security and Conservation Set-Aside in China. World Development, 34 (1), 130, 2006.

11. LIU Q., WANG Y.Q., ZHANG J., CHEN Y.P. Filling Gullies to Create Farmland on the Loess Plateau. Environmental Science \& Technology, 47 (14), 7589, 2013.

12. LIU Y.S., LI Y.R. Engineering philosophy and design scheme of gully land consolidation in Loess Plateau. Transactions of the Chinese Society of Agricultural Engineering, 33 (10), 1, 2019.

13. WEI Y.X., LIU Z.K., FENG D.R., SUN J.P., ZHANG Y.F. Influences of the biochar on physical properties of the meadow black soil and dynamic changes of soil water after the individual rainfall. Transactions of the Chinese Society for Agricultural Machinery, 47 (8), 201, 2016.

14. LIU Y.S., LI Y.H. Environment: china's land creation project stands firm. Nature, 511 (7510), 410, 2014.

15. XUE S., LIU G.B., ZHANG C., FAN L.X. Effects of terracing slope cropland on soil quality in Hilly Region of Loess Plateau. Transactions of the Chinese Society of Agricultural Engineering, 27 (4), 310, 2011.

16. YANG J., LIU L., SUN C.M., LIU X.F. Soil components and fertility improvement of added cultivated land. Transactions of the Chinese Society of Agricultural Engineering, 24 (7), 102, 2008.

17. MA C.Q., LIU T.M., YANG M.H. Analysis of soil nutrients of the newly-increased farmland in the process of land consolidation in Gaoling County. Journal of Northwest Agriculture and Forest University, 38 (5), 175, 2010.

18. HIMANSHU P., RAMANDEEP S., ARTI B., NIVETA J. Recycling of rice straw to improve wheat yield and soil fertility and reduce atmospheric pollution. Paddy and Water Environment, 4 (2), 111, 2006.

19. YANG H.S. Resource management, soil fertility and sustainable crop production: Experiences of China. Agriculture, Ecosystems and Environment, 116 (1), 27, 2006.

20. XU G., LV Y.C., SUN J.N., SHAO H.B., WEI L.L. Recent advances in biochar applications in agricultural soils: Benefits and environmental implications. Clean-Soil, Air, Water, 40 (10), 1093, 2012.

21. BASS A.M., BIRD M.I., KAY G., MUIRHEAD B. Soil properties, greenhouse gas emissions and crop yield under compost, biochar and co-composted biochar in two tropical agronomic systems. Science of the Total Environment, 550, 459, 2016.

22. GLASER B., BALASHOV E., HAUMAIER L., GUGGENBERGER G., ZECH W. Black carbon in density fractions of anthropogenic soils of the Brazilian Amazon region. Organic Geochemistry, 31 (7), 669, 2000. 
23. GLASER B., HAUMAIER L., GUGGENBERGER G., ZECH W. The "Terra Preta" phenomenon: a model for sustainable agriculture in the humid tropics. Die Naturwissenschaften, 88 (1), 37, 2001.

24. YANG S.H., SUN X., DING J., JIANG Z.W., XU J.Z. Effects of biochar addition on the NEE and soil organic carbon content of paddy fields under water-saving irrigation. Environmental Science and Pollution Research, 26 (8), 8303, 2019.

25. CHEN Y., LIU Y.X., CHEN C.J., LV H.H., WANG Y.Y., HE L.L., YANG S.M. Priming effect of biochar on the minerialization of native soil organic carbon and the mechanisms: A review. Chinese journal of applied ecology, 29 (1), 314, 2018.

26. AJAYI A.E., HOLTHUSEN D., HORN R. Changes in microstructural behavior and hydraulic functions of biochar amended soils. Soil and Tillage Research, 155, $166,2016$.

27. NOVAK J., SIGUA G., WATTS D., CANTRELL K., SHUMAKER P., SZOGI A., JOHNSON M.K., SPOKAS $\mathrm{K}$. Biochars impact on water infiltration and water quality through a compacted subsoil layer. Chemosphere, 142, $160,2016$.

28. OBIA A., MULDER J., MARTINSEN V., CORNELISSEN G., BØRRESENA T. In situ effects of biochar on aggregation, water retention and porosity in light textured tropical soils. Soil and Tillage Research, 155, 35, 2016.

29. ZHANG J.N., CHEN G.F., SUN H.F., ZHOU S., ZOU G.Y. Straw biochar hastens organic matter degradation and produces nutrient-rich compost. Bioresource Technology, 200, 876, 2016

30. YUAN J.J., TONG Y.A., LU S.H., YUAN G.J. Comprehensive evaluation on soil fertility quality of jujube orchard under combined application of biochar and nitrogen fertilizer. Transactions of the Chinese Society of Agricultural Engineering, 34 (01), 134, 2018.

31. TIAN X.F., LI C.L., ZHANG M., WAN Y.S., XIE Z.H., CHEN B.C., LI W.Q. Biochar derived from corn straw affected availability and distribution of soil nutrients and cotton yield. PLOS ONE, 13 (1), e 0189924, 2018.

32. KRAPFL K.J., HATTEN J.A., ROBERTS S.D., BALDWIN B.S., ROUSSEAU R.J., SHANKLE M.W. Soil properties, nitrogen status, and switchgrass productivity in a biochar amended silty clay loam. Soil Science Society of America Journal, 78 (S1), S136, 2014.

33. BAO S.D. Methods of Soil and Agro-chemical Analysis, 3rd ed.; China Agricultural Science and Technology Press: Beijing, China, 30, 2000 [In Chinese].

34. CHEN X.X., HE X.S., GENG Z.C., ZHANG W., GAO H.Y. Effects of biochar on selected soil chemical properties and on wheat and millet yield. Acta Ecologica Sinica, 33 (20), 6534, 2013.

35. LIU X., MA J., MA Z.W., LI L.H. Soil nutrient contents and stoichiometry as affected by land-use in an agropastoral region of Northwest China. Catena, 150, 146, 2017.

36. GUL S., WHALEN J.K., THOMAS B.W., SACHDEVA V., DENG H.Y. Physico-chemical properties and microbial responses in biochar-amended soils: Mechanisms and future directions. Agriculture, Ecosystems \& Environment, 206, 46, 2015.

37. ZHAO L., CAO X.D., ZHENG W., WANG Q., YANG F. Endogenous minerals have influences on surface electrochemistry and ion exchange properties of biochar. Chemosphere, 136, 133, 2015.
38. LI C.J., XIONG Y.W., QU Z.Y., XU X., HUANG Q.Z., HUANG G.H. Impact of biochar addition on soil properties and water-fertilizer productivity of tomato in semi-arid region of Inner Mongolia, China. Geoderma, 331, 100, 2018.

39. ZHANG J.G., XU X.W., LEI J.Q., SUN S.G., FAN J.L., LI S.Y., GU F., QIU Y.Z., XU B. The salt accumulation at the shifting aeolian sandy soil surface with high salinity groundwater drip irrigation in the hinterland of the Taklimakan Desert. Chinese Science Bulletin (in English), 53 (2 Supplement), 63, 2008.

40. CHENG C.H., LIN T.P., LEHMANN J., FANG L.J., YANG Y.W., MENYAILO O.V., CHANG K.H., LAI J.S. Sorption properties for black carbon (wood char) after long term exposure in soils. Organic Geochemistry, 70 (5), 53 , 2014.

41. ZHANG A.F., PAN G.X., LI L.Q. Biochar and the Effect on $\mathrm{C}$ Stock Enhancement, Emission Reduction of Greenhouse Gases and Soil Reclamation. Journal of Agro-Environment Science, 28 (12), 2459, 2009.

42. CHENG C.H., LEHMANN J., THIES J.E., BURTON S.D., ENGELHARD M.H. Oxidation of black carbon by biotic and abiotic processes. Organic Geochemistry, 37, 1477, 2006.

43. KUMAR T.S., SWAMINATHAN V., KUMAR S. Influence of nitrogen, phosphorus and biofertilizers on growth, yield and essential oil constituents in ratoon crop of davana (Artemisia pallens Wall.). Physical Review B-Condensed Matter, 80 (8), 1956, 2009.

44. WANG F., TONG Y.A., ZHANG J.S., GAO P.C., COFFIE J.N. Effects of various organic materials on soil aggregate stability and soil microbiological properties on the Loess Plateau of China. Plant Soil \& Environment, 59 (4), 162, 2013.

45. LI S.L., LIANG C.T., SHANGGUAN Z.P. Effects of apple branch biochar on soil $\mathrm{C}$ mineralization and nutrient cycling under two levels of $\mathrm{N}$. Science of the Total Environment, 607, 109, 2017.

46. KIMETU J.M., LEHMANN J. Stability and stabilization of biochar and green manure in soil with different organic carbon contents. Australian Journal of Soil Research, 48 (7), 577, 2010.

47. ATKINSON C.J., FITZGERALD J.D., HIPPS N.A. Potential mechanisms for achieving agricultural benefits from biochar application to temperate soils: a review. Plant and Soil, 337 (1-2), 1, 2010.

48. ZHANG Q.Z., WANG X.H., DU Z.L., LIU X.R., WANG Y.D. Impact of biochar on nitrate accumulation in an alkaline soil. Soil Research, 51 (6), 521, 2013.

49. GLASER B., LEHMANN J., ZECH W. Ameliorating physical and chemical properties of highly weathered soils in the tropics with charcoal-a review. Biology and Fertility of Soils, 35 (4), 219, 2002

50. CHEN J., WANG Y.Y., WU J.H., SI H.P. The Research of Biochar Adsorption on Soil. Applied Mechanics and Materials, 448, 417, 2013.

51. CHINTALA R., SCHUMACHER T.E., MCDONALD L.M., CLAY D.E., MALO D.D., PAPIERNIK S.K., CLAY S.A., JULSON J.L. Phosphorus Sorption and Availability from Biochars and Soil/Biochar Mixtures. CLEAN - Soil, Air, Water, 42 (5), 626, 2014.

52. LUO L., LV J.T., CHEN Z.E., HUANG R.X., ZHANG S.Z. Insights into the attenuated sorption of organic compounds on black carbon aged in soil. Environmental Pollution, 231 (2), 1469, 2017

53. NOGUERA D., RONDÓN M., LAOSSI K.R., HOYOS V., LAVELLE P., CARVALHO M.H.C.D., BAROT S. 
Contrasted effect of biochar and earthworms on rice growth and resource allocation in different soils. Soil Biology and Biochemistry, 42 (7), 1017, 2010.

54. WU Y.H., TIAN X.H., NAN X.X., CHI W.B., YAN X.L., ZHU R.X., TONG Y.A. Evaluation of soil quality under conservation tillage via factor and cluster analyses. Chinese Journal of Eco-Agriculture, 18 (2), 223, 2010.

55. TABATABAI M., BREMNER J. Use of p-nitrophenyl phosphate for assay of soil phosphatase activity. Soil Biology and Biochemistry, 1 (4), 301,1969.

56. DING M.L., LU Y.G., ZHAO C., WANG J.S. Changes of Ammonification and Nitrification Intensity of SoiI Nitrogen in Tobacco Field. Guizhou Agricultural Sciences, 34 (4), 36, 2006.

57. STEINER C., GLASER B., GERALDES T.W., LEHMANN J., WINFRIED E.H.B., ZECH W. Nitrogen retention and plant uptake on a highly weathered central Amazonian Ferralsol amended with compost and charcoal. Journal of Plant Nutrition and Soil Science, 171, 893, 2008.

58. JIN Z.W., CHEN C., CHEN X.M., JIANG F., HOPKINS I., ZHANG X.L., HAN Z.Q., BILLY G., BENAVIDES J. Soil acidity, available phosphorus content, and optimal biochar and nitrogen fertilizer application rates: A five-year field trial in upland red soil, China. Field Crops Research, 232, 77, 2019.

59. CLARE A., SHACKLEY S., JOSEPH S., HAMMOND J., PAN G.X., BLOOM A. Competing uses for China's straw: the economic and carbon abatement potential of biochar. Global Change Biology Bioenergy, 7 (6), 1272, 2015.

60. DONG X.L., GUAN T.Y., LI G.T., LIN Q.M., ZHAO X.R. Long-term effects of biochar amount on the content and composition of organic matter in soil aggregates under field conditions. Journal of Soils and Sediments, 16 (5), 1481, 2016.

61. LIANG F., LI G.T., LIN Q.M., ZHAO X.R. Crop Yield and Soil Properties in the First 3 Years after Biochar Application to a Calcareous Soil. Journal of Integrative Agriculture, 13 (3), 525, 2014.

62. JEONG K.W., KIM B.S., ULTRA V.U., SANG C.L. Effects of rhizosphere microorganisms and wood vinegar mixtures on rice growth and soil properties. Korean Journal of Crop Science, 60 (3), 355, 2015. 